\title{
Recurrent Idiopathic Facial Paralysis: A Case Report
}

\author{
Tekrarlayan Idiyopatik Fasial Paralizi: Olgu Sunumu
}

\author{
Hale Hekim Baloğluㄹ, Serpil Savaş ${ }^{1}$, Feride Ekimler Süslü${ }^{1}$, Mustafa Tüz \\ ISüleyman Demirel Üniversitesi Tıp Fakültesi, Fiziksel Tıp ve Rehabilitasyon Anabilim Dalı, Isparta, Turkey \\ 2Süleyman Demirel Üniversitesi Tıp Fakültesi, Kulak Burun Boğaz Hastalıkları Anabilim Dalı, Isparta, Turkey
}

\begin{abstract}
Idiopathic facial paralysis is the mononeuropathy Multiple recurrences of idiopathic facial paralysis in a patient may be the sign or sympton of a serious illness. therefore; in recurrent cases, family history, systemic diseases and malignancy must be investigated. In this report, a case of recurrent idiopathic facial paralysis is presented. (Turk $J$ Rheumatol 2010; 25: 162-4)

Key words: Facial paralysis, idiopathic, recurrent
\end{abstract}

Received: 26.12 .2008

Accepted: 16.03 .2009

\section{Özet}

İdiyopatik fasial paralizi, yedinci kranial sinirin mononoropatisidir ve olguların yaklașık \%2-9'unda tekrarlama eğilimindedir.Birçok kez tekararlayan idiyopatik fasial paralizi ciddi bir hastalığın belirtisi yada semptomu olabilir. Bu nedenle tekararlayan idiyopatik fasial paralizisi olan bir hastamız sunulmaktadır. (Turk J Rheumatol 2010; 25: 162-4)

Anahtar sözcükler: Fasial paralizi, idiyopatik, tekrarlayıcı

Alındığı Tarih: 26.12.2008 Kabul Tarihi: 16.03.2009

\section{Introduction}

Idiopathic facial paralysis is the acute mononeuropathy of the seventh cranial nerve, and it is recurrent in $2-9 \%$ of the cases $(1,2)$. The first recurrence is usually observed within 10 years (1). As the number of recurrences increases, the incidence rate decreases. Multiple recurrences of idiopathic facial paralysis in a patient may be the sign or symptom of a serious illness. Therefore, systemic diseases such as hypertension, diabetes and tumors that might cause facial nerve compression should be investigated in patients with recurrent idiopathic facial paralysis. Moreover, cases of recurrent idiopathic facial paralysis may be familial (1). It is thus critical to acquire a detailed family history of the patient. In this case report, a patient with recurrent idiopathic facial paralysis is presented along with a review of the relevant literature.

\section{Case Presentation}

A 52-year-old female patient with right idiopathic facial paralysis for three weeks admitted to our outpatient clinic. The patient had a history of hypertension for 17 years and diabetes for 15 years. She was on oral antihypertensive and oral anti-diabetic drugs. She had used steroids for five weeks before her admission to our outpatient clinic. The patient's history did not indicate the use of any other drugs. She experienced left facial paralysis three times (in 1998, 2003 and 2004; two ipsilateral and one contralateral). Her sister also reported an episode of right idiopathic peripheral facial paralysis, but only once, and without recurrence. The patient did not have any history of recurrent viral infection, alcohol consumption or smoking.

The patient's face appeared asymmetric on physical examination. The right side of her forehead did not show any wrinkles, and the nasolabial groove was deepened. She was not able to raise her right eyebrow, blink her right eye or frown. She could not show her teeth on the right side of her mouth or whistle (Figure 1). The patient had grade VI facial nerve paralysis according to the HouseBrackmann facial nerve stages grading system (3). Her blood count, erythrocyte sedimentation rate, C-reactive protein, biochemistry, thyroid function tests, and vitamin B12 values were normal. Electroneuromyography (ENMG) examination was performed four weeks after the patient was paralyzed, and the electrophysiologic findings 


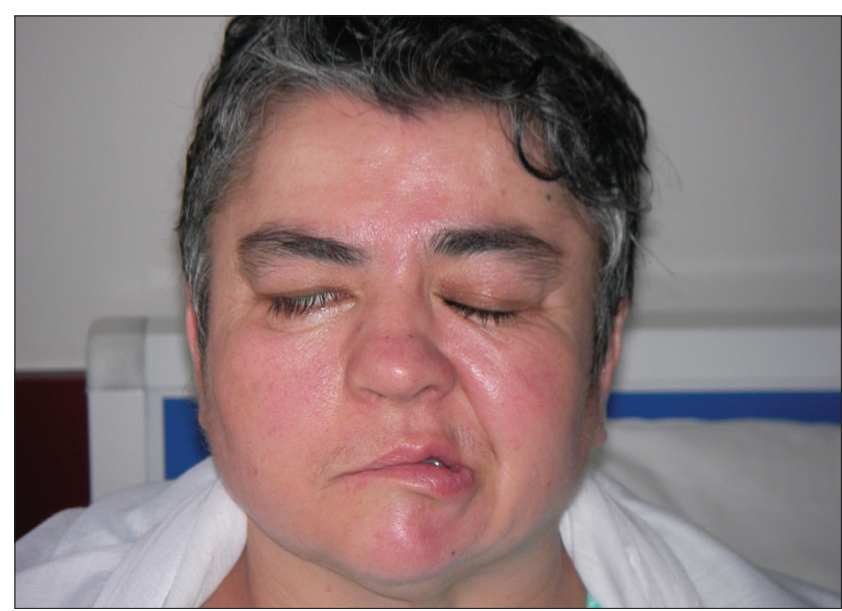

Figure 1. The patient's facial appearance

indicated total axonal degeneration of the right facial nerve and partial mild and chronic effects on the left facial nerve. To eliminate the possibility of a mass that would cause trans-mastoidal compression, internal acoustic canal magnetic resonance imaging (MRI) was performed, and the results were normal. Audiogram was normal. Results of cranial MRIs (with and without contrast), which were done to address the possibility of an intracranial mass, were also normal. Upon the diagnosis of idiopathic facial paralysis, the patient was treated with a 36-session physical therapy program that consisted of regular applications of hot pack (on right tragus, for 20 minutes), therapeutic ultrasound (on right tragus, $1 \mathrm{~W} /$ $\mathrm{cm}^{2}, 5$ minutes), electrical stimulation (right side of facial muscles) and facial exercises. The patient was discharged with sequelae findings (House-Brackmann grade V).

\section{Discussion}

In $70 \%$ of the patients with recurrent idiopathic facial paralysis, the first recurrence is observed within 10 years (4). It should be noted that the first recurrence in the case presented here was observed after five years, in accordance with the literature. The recurrence of idiopathic facial paralysis on the ipsilateral or contralateral side may be the sign of an underlying serious illness. In a study by May et al. (5), a tumor was found in $30 \%$ of the patients with recurrent ipsilateral facial paralysis. It has also been reported that cranial nerve involvement may sometimes be the first sign of neuro-meningeal lymphoma (6). Therefore, in the present case, as a first step, we investigated and eliminated the possibility of a tumor. In pregnancy, hypertension and diabetes mellitus increase the risk of developing recurrent idiopathic facial paralysis (7). In a study by Devriese et al. (7), a significant association was found between recurrent idiopathic facial paralysis and high blood pressure. In the case of our patient, the existence of a long-standing diabetes and hypertension led us to believe that these illnesses might be the cause of the recurrence of the patient's facial paralysis. The fact that our patient's sister also had facial paralysis suggests a familial tendency in the case of the facial paralysis of our patient. Among the cases of recurrent idiopathic facial paralysis, there is a 2.5 times greater probability of a family history of this illness (1). Familial and hereditary recurrent idiopathic facial paralysis have been reported with many families. Yanagihara et al. (8) reported the incidence of familial idiopathic facial paralysis to be $4 \%$ and the repetition rate of facial paralysis to be $11 \%$.

It has been reported that recurrent idiopathic facial paralysis might occasionally be a symptom of the neurological involvement of Behçet's disease (9). In our patient, we did not find any signs or symptoms of Behçet's disease. Another rare cause of recurrent idiopathic facial paralysis is Melkersson-Rosenthal syndrome (10). In this syndrome, recurrent episodes of swelling of the lips and face, tongue and recurrent facial paralysis attacks are observed. Since there was no indication of the symptoms of Melkersson-Rosenthal syndrome in our patient's history, this syndrome was not considered as a possible diagnosis.

Lyme disease is among the very common causes of bilateral or recurrent facial paralysis $(11,12)$. However, no clinical findings of Lyme disease such as erythema migraines, fever, fatigue or arthritis were observed during the physical examination or in the patient's medical history. Also, the bilateral facial paralysis cases with an underlying Lyme disease have mostly been reported in childhood. Therefore, the possibility of Lyme disease was excluded in the differential diagnosis.

Although rarely seen, recurrent idiopathic facial paralysis might be observed with Ramsay Hunt syndrome. Ramsay Hunt syndrome (herpes zoster oticus) is the infection of geniculate ganglia by varicella zoster. The symptoms of this syndrome are unilateral facial paralysis, ear pain, external ear canal or oral mucosa at the entrance of the herpetic rash, tinnitus, hearing loss, nausea, vomiting, vertigo, and nystagmus (13). In the literature, there has only been a single case report in which this syndrome was associated with recurrent unilateral facial paralysis (14). In that case report, the facial paralysis was recurrent on the same side. In the case presented here, the recurrence was bilateral. Moreover, the clinical findings of Ramsay Hunt syndrome were not observed in our patient's history, which led us to exclude this diagnosis.

In a retrospective study by Van Amstel et al. (4), 98 recurrent idiopathic facial paralysis patients were examined. Among them, 11 patients had three or more attacks of ipsilateral and contralateral facial paralysis, while three patients developed three or more attacks of ipsilateral paralysis only. In the case of ipsilateral recurrent paralysis, the response to treatment was found to be worse. In a study of Hallmo et al. (15), it was reported that permanent sequelae were seen more often in the cases of ipsilateral recurrent facial paralysis. Unlike the 
cases in the literature, in our patient, who experienced many recurrent idiopathic facial paralysis attacks (3 ipsilateral, 1 contralateral), permanent sequelae developed on the contralateral side. While for most of the patients with idiopathic facial paralysis, sequelae may improve without treatment, for some, minor facial dysfunction sequelae remain. Physical therapy agents are often used in the treatment of idiopathic facial paralysis cases, but the effectiveness is not very well known. Controlled clinical trials of physical therapy agents have also shown agents to be of no benefit or even harmful. Facial exercises are known to reduce recovery time and decrease sequelae (16).

In conclusion, recurrence may be seen in a small number of idiopathic facial paralysis patients. Systemic diseases of diabetes and hypertension should be considered as an underlying reason in cases of recurrent idiopathic facial paralysis, especially when both ipsilateral and contralateral paralysis are observed. Further, it should be noted that patients with recurrent idiopathic facial paralysis might have a familial predisposition.

\section{Conflict of Interest}

No conflict of interest is declared by authors.

\section{References}

1. Pitts DB, Adour KK, Hilsinger RL, Oakland CA. Recurrent Bell's palsy: analysis of 140 patients. Laryngoscope 1988; 98 : 535-40.

2. Yanagihara N, Mori H, Kozawa T, Nakamura K, Kita M. Bell's palsy-nonrecurrent vs. recurrent, unilateral versus bilateral. Arch Otolaryngol 1984; 110(6): 374-7.

3. Yen $T L$, Driscoll CL, Lalwani AK. Significance of HouseBrackmann facial nerve grading global score in the setting of differential facial nerve function. Otol Neurotol 2003; 24: 118-22.

4. van Amstel $A D$, Devriese PP. Clinical experiences with recurrences of Bell's palsy. Arch Otorhinolaryngol 1988; 245 : 302-6.

5. May M, Hardin WB. Facial palsy: interpretation of neurological findings. Laryngoscope 1978; 88: 1352-62.

6. Bodénez C, Vargaftig J, Barré P, Mansour G, Lamas G, Tankere E. Bilateral and recurrent facial paralysis due to lymphoma: a case report. Rev Laryngol Otol Rhinol 2007; 128 (1-2): 69-72.

7. Devriese PP, Schumacher $T$, Scheide $A$, de Jongh $R H$, Houtkooper JM. Incidence, prognosis and recovery of Bell's palsy. A survey of about 1000 patients (1974-1983). Clin Otolaryngol Allied Sci 1990; 15: 15-27.

8. Yanagihara N, Yumoto E, Shibahara T. Familial Bell's palsy. Analysis of 25 families. Ann Otol Rhinol Laryngol Suppl 1988; 137: 8-10.

9. Menassa J, Sawaya R, Masri AF, Arayssi T. Recurrent peripheral facial paresis may constitute the sole clinical manifestation in neuro-behcet disease. Neurologist 2008; 14: 77.

10. Kanerva M, Moilanen K, Virolainen S, Vaheri A, Pitkaranta A. Melkersson-Rosenthal syndrome. Otolaryngol Head Neck Surg 2008; 138: 246-51.

11. Halperin JJ. Lyme disease and the peripheral nervous system. Muscle Nerve 2003; 28: 133-43.

12. Smith V, Traquina DN. Pediatric bilateral facial paralysis. Laryngoscope 1998; 108(4): 519-23.

13. Sweeney CJ, Gilden DH. Ramsay Hunt syndrome. J Neurol Neurosurg Psychiatry 2001; 71: 149-54.

14. Pino Rivero V, González Palomino A, Pantoja Hernández CG, Mora Santos ME, Trinidad Ramos G, Blasco Huelva A. [Ramsay Hunt syndrome associated to unilateral recurrent paralysis]. An Otorrinolaringol Ibero Am 2006; 33: 489-94.

15. Hallmo P, Elverland HH, Mair IW. Recurrent facial palsy. Arch Otorhinolaryngol 1983; 237: 97-102.

16. Teixeria LJ, Soares BG, Vieira VP, Prado GF. Physical therapy for Bell's palsy (idiopathic facial paralysis). Cochrane Database Syst Rev 2008; 16: CD006283. 